\title{
Seasonal Variations in the Phosphate and Silicate Content of Sea Water during 1926 and 1927 in Relation to the Phytoplankton Crop.
}

\author{
By \\ W. R. G. Atkins, Sc.D., F.R.S., \\ Head of the Department of General Physiology at the Plymouth Laboratory.
}

Matthews $(1916,1917)$ was the first to observe that in early summer the surface water of the sea just outside Plymouth Breakwater is almost completely devoid of phosphate, owing to its utilization by algæ, fixed and planktonic. Brandt (1916-20) using Raben's (1916-20) analyses noted, in the Baltic especially, a minimum phosphate content in June, but this minimum was far from denoting complete exhaustion.

Later, Atkins (1923,'25,'26), using methods of analysis entirely different from those employed by Matthews or by Raben, obtained results in close agreement with those of Matthews, and showed that even twenty miles out to sea, at the International Hydrographic Station E1, the surface water was entirely deprived of phosphate in summer. As the season advanced the deeper water became at first very much poorer in phosphate and later on rather richer again, according as this salt was used up by the phytoplankton and then regenerated by the decay of animal and plant cells and by the excretion of animals. It was further shown by Atkins and Wilson (1927) that Brandt's curve did not indicate complete exhaustion of phosphate because the method of analysis employed included arsenic, originally present as arsenite, but oxidised to arsenate and precipitated with the phosphate. Reasons were adduced for the belief that the amount of arsenic present in the sea as arsenate is very minute and is all used up in summer by the algæ. It is doubtful whether any analyses yet made have distinguished the trace of arsenate, if indeed it exists, from phosphate.

Since the phosphate content of the various species of the phytoplankton, mainly diatoms, may be assumed to be similar, a study of the phosphate changes affords a measure, in an inverse ratio, of the production of the algal crop, and indicates from year to year the variations that occur in its seasonal waxing and waning. Such studies have shown that between the spring outbursts of activity as much as two months' difference may be noted in successive years. The variations 
observed here in the phosphate content showed a general correlation with the early spring daily sunshine average. When sunshine reached about three hours daily the increase in diatoms, as indicated by decrease in phosphate, became marked. Marshall and Orr (1927), however, found a remarkable constancy in the date of the vernal diatom outburst in the Clyde area. Their phosphate observations were checked by estimations of the diatom chains, a good agreement being found. They consider the length of the day, rather than the amount of sunshine, to be the most important factor. Working with a muffed glass receiving surface mounted over a photoelectric cell, Poole and Atkins (1926) found that in September - which may be considered as more or less comparable to April-the ratio of the reading with the cell exposed horizontally to full sunlight to that obtained when the direct rays of the sun were cut ofi, so that the cell received diffuse light only, was about 3.5 under clear conditions, falling to about two with weak sunlight and hazy or cloudy sky, so that the diffused light was high. These figures are not accurate measures of the ratio of total light to difituse light, since the average obliquity of the diffuse light was not identical with that of the sun's rays, but it serves well as a comparison. It appears then that the effect of full sunshine is to raise the general illumination by three hundred or three hundred and fifty per cent with respect to a horizontal surface, and since a diatom may be considered as set at the most advantageous angle to the incident light the eifect must be even greater. In any case an hour of direct sunlight is at least equivalent to two hours of the diffuse light of a sunny day, and it may be equivalent to three hours or more. On a grey day a specially dark cloud has been observed to reduce the general illumination to one-sixth within a period of three minutes, so it may be realized that it is not easy to correlate either sunshine or length of day with diatom growth, even assuming that the latter were to act as a reliable integrating agent. Angström (1924), however, has found that the following formula fits in well* with the data obtained at Washington and Stockholm for daily sunshine, length of day and total solar radiation, direct or indirect.

Where $\mathrm{S}=$ the proportion of the actual to the possible hours of sunshine during the day,

$\mathrm{Q}_{0}=$ the solar radiation corresponding to a perfectly clear day,

$\mathrm{Q}_{\mathrm{s}}=$ the solar radiation recorded at the place of observation (mean value for each month),

then $\mathrm{Q}_{\mathrm{s}}=\mathrm{Q}_{\mathrm{O}}(0 \cdot 25+0 \cdot 75 \mathrm{~S})$.

From the form of the equation it is clear that on a clear day (or month)

* Haines (1925) found that the variation at Rothamsted was on the whole of the same order as that found by Angström at Stockholm, but the general tendency was to give too low values at Rothamsted. 
$\mathrm{Q}_{\mathrm{s}}=\mathrm{Q}_{\mathrm{o}}$, and the ratio $\mathrm{S}$ becomes unity; accordingly under these conditions the fact that the equation is a fairly good representation of the observed data shows that the diffuse radiation is one-third of the direct sunlight, for the figures inside the bracket are now unity. On the other hand, with a ten-hour day and one hour sunshine the relative values for difíuse and direct radiation become $0 \cdot 25$ and $0 \cdot 075$. With $3 \frac{1}{3}$ hours of sunshine and a ten-hour day the dififuse and direct radiation become equal; with a twelve-hour day the ratio would be unity with four hours sunshine daily. It is more or less under these conditions, a ten-twelvehour day-before the vernal equinox-and about three hours a day sunshine that the diatom outburst appears ; so from the above considerations it seems that the sunshine effect, for the few hours it lasts, must be about equal to that of the diffuse radiation. Since the length of the day at the same season is, of course, the same from year to year it is to the sunshine effect* that one must look for the large amount of extra energy necessarily used up in the vernal diatom outburst, which may come earlier one year than another.

Three other factors, however, may affect the illumination to which the diatoms are exposed, though the factors are not necessarily or even probably unrelated. Firstly, the turbidity of the water in a given locality may vary at the same season in different years due to difference in plankton content or to suspended inorganic matter, whether occasioned by a variation in currents or to stirring up of bottom deposits. Secondly, the amount of light reflected at the surface may vary, photoelectric measurements having shown that on a calm day with glassy surface as little as five per cent is lost at the water surface, whereas with a wind causing waves to break the loss may amount to thirty-one per cent and doubtless to more under stormy conditions. Thirdly, since diatoms multiply by continued doubling when under suitable conditions as regards illumination, nutrient salts and temperature, it is clear that, starting with a small number of diatoms some time must elapse before any depletion of phosphate can be detected. Assuming for simplicity that the doubling occupies one day under certain conditions, and that at the detectable limit, $1 \mathrm{mg}$. per cubic metre of phosphate, reckoned as $\mathrm{P}_{2} \mathrm{O}_{5}$, is used up in one day. The next day $2 \mathrm{mg}$. will be used, then $4,8,16$ in the succeeding days, so that in five days $31 \mathrm{mg}$. would have been consumed, namely, the surface water would have been reduced from its winter maximum of $36-40 \mathrm{mg}$. down to $5-9 \mathrm{mg}$. Such a rapid falling off, within a month or even probably a fortnight-possibly less-has been observed. The fall taking place in a fortnight would correspond to a doubling in three days. If, however, when the diatoms have reached

* It is of course obvious that the energy received on earth from one hour's sunshine depends both on the time of the day and upon the season.

NEW SERIEs, - VOI, xv. No. 1. FEBRUARY, 1928. 
the $1 \mathrm{mg}$. per day (or per three days) stage in the surface metre under good illumination, stormy weather ensues, with, we will suppose, the result that the water mass - which in spring is isothermal-becomes well mixed to a considerable depth, it is obvious that the number of diatoms at the surface will have become reduced far below the detectable limit of action. If the water has been thoroughly mixed to 16 metres the average number of diatoms will have been reduced to one-sixteenth, and when good lighting conditions are restored at the surface at least five days - on the one-day doubling rate, or fifteen on the three-day rate-must elapse before the detectable limit of phosphate consumption is again reached. It might be supposed accordingly that in calm weather a diatom outburst could take place under conditions of illumination inadequate when stormy.

In order to test this hypothesis the meteorological records for Plymouth (Cattewater) were examined for the periods in 1923-1925, during which the vernal diatom outbursts were most marked. Table 1 shows the velocity of the wind, on the Beaufort Scale (0-12), on which three denotes

TABLE 1.

Showing Phosphate Consumption as Milligrams $\mathrm{P}_{2} \mathrm{O}_{5}$ Per $\mathrm{M}^{3}$. IN the Surface Water at Station El, and the Strength and Direction of the Wind from Plymouth Records.

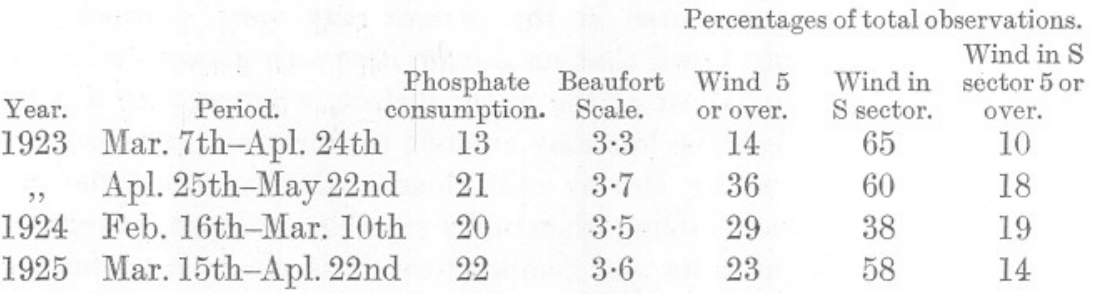

8-12 statute miles per hour, four 13-18, five 19-24, six 25-31, and seven $32-38$. No records above seven were found during the periods. Our vessel, the Salpa, has carried out hydrographic work at Station E1 with wind five on the scale. It is at once obvious that there is no connection between the date of the outburst and the average value for the wind. Neither can any correlation be made out between the date of the outburst and the delaying action of strong winds-over five on the scale. Since wind from the southerly sector, between east and west, inclusive, is more potent at E1 in bringing about. a heavy sea than is wind from the northerly sector the percentages of the total observations with south sector winds are shown in column 6 , and the percentage of strong south sector winds in column 7 . The only relation that may possibly be made 
out is that in 1924, when the outburst came very early, north sector winds predominated, though within the same period rough weather from the south was at its highest with 19 per cent five or over. The relation works back to the sunny weather and clear skies associated with northerly winds. The results of this comparison show that at an open station, such as E1, the strength of the wind is not a factor of any importance in bringing about differences in the dates of the vernal diatom outbursts. It cannot accordingly be effective in mixing the water in the manner supposed so as to carry down the diatoms into regions of inadequate illumination; it may be remarked that the light that does penetrate into the water is about halved at 5 metres depth at E1. The agreement between the sunshine record and the diatom outburst dates still seems to indicate that direct sunlight with the general good lighting conditions that accompany it is the one factor most potent in bringing about diatom multiplication in open water rich in nutrient salts. The sunshine records are shown in Fig. 5 (Atkins, 1926, Phosphate III). It may be explained that the concluding sentence of the legend under Fig. 5 should be deleted, as it belongs to the legend of Fig. 3 and has been repeated in error. For the present, therefore, no explanation can be given of the discrepancy between the E1 results and those for the Clyde area, where the length of the day appears to control the date of the vernal diatom outburst (Marshall and Orr, Fig. 9). Wind and tide are admittedly effective in their area as regards vertical mixing, but that hardly makes the solution of the problem any easier. Herdman, Scott, and Dakin (1910) have also correlated the early spring sunshine with the diatom outburst at Port Erin, 1907 having an unusually early diatom crop following, with a lag, a high value for February sunshine.

In autumn the surface cooling sets up convection currents and produces a very thorough mixing of the water. While this is in progress diatoms multiplying near the surface will be carried down into regions of lesser illumination, so it is unlikely that an outburst will occur till after the water has become isothermal.

Data already presented (Atkins, 1926, 1 and 2; Harvey, 1926) have traced the changes in silicate, phosphate and nitrate over periods of one or more years. The results now published extend these, and an attempt is being made to correlate the variations in these minor constituents of sea-water, which are of special importance to the phytoplankton.

\section{Seasonal Changes in Phosphate and Silicate Concentration.}

The data recorded in Table 2 merely confirm previous results as to the generally insignificant effect of land drainage upon phosphate content, though at L1, under the Laboratory, an occasional high value is found. 
This series has been discontinued, save for the surface and bottom (40 m.) observations at L4, half-way between Rame Head and the Eddystone. Here, as at E1, during the autumn and early winter the surface values are sometimes in excess of the bottom, due apparently to regeneration of phosphate from bodies either floating or suspended in the upper layers. No corresponding silicate estimations were made, as it had already been shown that there was a fairly steep gradient from the Sound to L4 or sometimes to E1, from which on to E3 (Ushant) there was but little change.

In Table 3 are shown the seasonal changes in phosphate and silicate, also the temperatures for 1926 to March 1927, from which time the analyses were discontinued on account of illness. The phosphate series had been unbroken from March 1923, for four years. In 1926 a rapid fall in phosphate, extending to the bottom, took place at the end of March or early in April, rather earlier than in 1925, and going deeper, rather later than in 1924, though deeper than then also; 1923 was a very late year since the fall did not occur till May. The results are plotted in Fig. 1 for the upper $5 \mathrm{~m}$., and Fig. 2 (of the accompanying paper by H. W. Harvey, Journ. Mar. Biol. Assoc., Vol. XV, p. 186) for the bottom, $70 \mathrm{~m}$., together with those for nitrate, and are further discussed together with the nitrate analyses in Harvey's paper.

The silica analyses for E1 were all carried out upon water collected in large bottles coated internally with paraffin wax to meet the haunting suspicion that an occasional high result might be due to silicate from the bottle. A number of other results were obtained, using water from the ordinary green glass spring clip milk bottles in vogue for sea-water samples in general. These gave no reason for thinking that their use was illegitimate for short periods of storage - a conclusion reached before (Atkins, 1923). However, the waxed bottles provide a large sample conveniently and with absolute certainty that storage can add no silica save in so far as suspended matter may dissolve.

It must be pointed out, however, that these waxed bottles are not suitable for water destined for the analysis of phosphate, but they may give results in perfect accord - if the bottle has been freshly waxed it seems. Thus values such as 26 in glass, 26 in wax, and 20 in glass, 19 in wax were obtained in two comparisons. The waxed bottles usually, however, give lower results, such as 32 in glass, 25 and again 25 in wax. Two possibilities presented themselves, firstly that the uncoated bottles had contained floating matter rich in phosphate or had been accidentally contaminated - but the consistence with which such high values appeared only in the uncoated bottles ruled this out in time; secondly, that the large waxed bottles, which usually had one sample standing in them till taken to sea for another, afforded a resting-place for moulds which, 


\section{TABLE 2 .}

Phosphate Content of Surface Samples (also 40 M. for L4) at Stations from the Laboratory to El from Feb., 1926-March, 1927, expressed as MG. Per $\mathrm{M}^{3}$. of $\mathrm{P}_{2} \mathrm{O}_{5}$. "A " indicates date on which the Analyses were made.

\begin{tabular}{l|c|c|c|c|c|c|c|c|c|c|c|c|c|c}
\hline & $\begin{array}{c}\text { Feb. } \\
\text { 3rd. }\end{array}$ & $\begin{array}{c}\text { Mar. } \\
\text { 11th. }\end{array}$ & $\begin{array}{c}\text { Apl. } \\
\text { 10th. }\end{array}$ & $\begin{array}{c}\text { May } \\
\text { 17th. }\end{array}$ & $\begin{array}{c}\text { June } \\
24 \text { th. }\end{array}$ & $\begin{array}{c}\text { July } \\
\text { 8th. }\end{array}$ & $\begin{array}{c}\text { Ang. } \\
16 \text { th. }\end{array}$ & $\begin{array}{c}\text { Sept. } \\
22 \text { 2nd. }\end{array}$ & $\begin{array}{c}\text { Oet. } \\
19 \text { th. }\end{array}$ & $\begin{array}{c}\text { Nor. } \\
24 \text { th. }\end{array}$ & $\begin{array}{c}\text { Dec. } \\
14 \text { th. }\end{array}$ & $\begin{array}{c}\text { Dec. } \\
\text { 31st. }\end{array}$ & $\begin{array}{c}\text { Feb. } \\
15 \text { th. }\end{array}$ & $\begin{array}{l}\text { Mar. } \\
21 \text { st. }\end{array}$ \\
\hline L1 & 38 & - & - & - & - & - & 100 & - & - & - & - & - & - & - \\
L2 & - & - & - & - & - & - & 29 & - & - & - & - & - & - & - \\
L3 & 33 & - & - & - & 7 & - & 24 & - & - & - & - & - & - & - \\
L4 & 39 & $25^{*}$ & - & $9^{*}$ & 5 & - & 10 & 17 & 29 & 43 & 32 & 34 & 52 & 25 \\
L40 m. & 33 & 40 & - & 12 & 30 & - & 8 & 11 & 17 & 19 & 33 & 22 & 31 & 28 \\
L5 & 33 & - & - & - & 4 & - & 28 & 22 & 27 & 26 & - & - & - & - \\
L6 & - & - & - & 7 & - & - & 2 & 14 & 36 & - & - & - & - & - \\
E1 & 30 & 25 & $10^{*}$ & 5 & 4 & 7 & 0 & 15 & 26 & 41 & 32 & 27 & 24 & 25 \\
A & $5 / 2$ & $13 / 3$ & $26 / 4$ & $19 / 5$ & $25 / 6$ & $13 / 7$ & $18 / 8$ & $4 / 10$ & $20 / 10$ & $26 / 11$ & $15 / 12$ & $3 / 1 / 27$ & $24 / 2$ & $22 / 3$ \\
\hline
\end{tabular}

\section{TABLE 3 .}

Station E1, February 1926-March 1927. Phosphate as $\mathrm{P}_{2} \mathrm{O}_{5}$ and Silicate as $\mathrm{SiO}_{2}$, in Milligrams per Cubic Metre. The values FOR SILICA ARE ONLY SHOWN FOR 0 AND $70 \mathrm{M}$. "A" INDICATES THE DATE ON WHICH THE ANALYSES IMMEDIATELY abOve WERE made. Temperatures are shown at the bottom of the Table.

\begin{tabular}{|c|c|c|c|c|c|c|c|c|c|c|c|c|c|c|}
\hline M & $\begin{array}{l}\text { Feb. } \\
\text { 3rd. }\end{array}$ & $\begin{array}{l}\text { Mar. } \\
\text { 11th. }\end{array}$ & $\begin{array}{l}\text { Apl. } \\
\text { 10th. }\end{array}$ & $\begin{array}{c}\text { May } \\
17 \text { th. }\end{array}$ & $\begin{array}{c}\text { June } \\
\text { 24th. }\end{array}$ & $\begin{array}{l}\text { July } \\
\text { 8th. }\end{array}$ & $\begin{array}{l}\text { Aug. } \\
\text { 16th. }\end{array}$ & $\begin{array}{l}\text { Sept. } \\
\text { 22nd. }\end{array}$ & $\begin{array}{l}\text { Oct. } \\
\text { 19th. }\end{array}$ & $\begin{array}{l}\text { Nov. } \\
\text { 24th. }\end{array}$ & $\begin{array}{l}\text { Dec. } \\
\text { 13th. }\end{array}$ & $\begin{array}{l}\text { Dec. } \\
\text { 31st. }\end{array}$ & $\begin{array}{l}\text { Feb. } \\
\text { 15th. }\end{array}$ & $\begin{array}{l}\text { Mar. } \\
\text { 21st. }\end{array}$ \\
\hline 0 & 30 & $25^{*}$ & $10 *$ & $5^{*}$ & 4 & 7 & 0 & 15 & 26 & 41 & & 27 & 4 & 41 \\
\hline 5 & 3 & 3 & - & 12 & 10 & 4 & 0 & & 17 & 24 & & 23 & 28 & 27 \\
\hline 10 & $3:$ & 3 & - & - & 10 & 4 & 0 & 0 & - & $\longrightarrow$ & 25 & - & - & - \\
\hline 15 & - & 37 & - & 12 & 11 & 7 & 2 & 0 & - & - & - & - & - & - \\
\hline 20 & - & - & - & - & 12 & 11 & 14 & 1 & - & - & - & - & - & - \\
\hline 25 & - & 39 & - & 12 & 17 & 13 & 14 & 15 & 17 & - & 29 & 20 & - & 28 \\
\hline 30 & - & - & - & - & 20 & - & - & 13 & - & - & - & - & - & - \\
\hline 50 & - & 37 & - & 14 & - & 12 & 14 & 10 & - & - & 29 & - & - & - \\
\hline 70 & 33 & 37 & 9 & 15 & 23 & 12 & 13 & 9 & 20 & 26 & 27 & 22 & 28 & 30 \\
\hline A & 5th & 13th & $26 \mathrm{th}$ & 19th & 25 th & 13th & 18th & lst & 20 th & 26 th & $15 \mathrm{th}$ & $3 \mathrm{rd}$ & 24th & 22 nd \\
\hline 0 & 175 & 80 & - & 40 & 55 & 75 & 36 & 70 & 94 & 263 & 168 & 104 & 260 & 144 \\
\hline 70 & - & 90 & - & 40 & 55 & - & 44 & 130 & 108 & 134 & 168 & 104 & 26 & 250 \\
\hline A & 6th & 14th & - & 20th & 28th & 14th & 18th & 6th & $21 \mathrm{st}$ & 27 th & 17th & 4th & $3 \mathrm{rd}$ & 24th \\
\hline 0 & & & $10 \cdot 2$ & & $14 \cdot 3$ & & & & & & 11 & 10. & & \\
\hline 70 & $9 \cdot 4$ & $9 \cdot 4$ & $9 \cdot 6$ & $10 \cdot 5$ & $11 \cdot 3$ & $11 \cdot 8$ & $12 \cdot 6$ & $13 \cdot 5$ & $14 \cdot 5$ & $12 \cdot 2$ & 11.7 & $10 \cdot 3$ & $9 \cdot 4$ & $9 \cdot 0$ \\
\hline
\end{tabular}

* All values for phosphate in March, April and May may be too high, as the standard had deteriorated and the correction applied is only an approximation. The figures for each month are, however, consistent among themselves. 
owing to the wax, could not be seen. Evidence in support of the mould theory was afforded when the sample, which had previously given $25 \mathrm{mg}$. per $\mathrm{m}^{3}$. twice, was shaken up and again analysed when the values 16 and 15 were obtained, showing clearly that phosphate had been removed from the lower portion of the bottle to a greater extent than from the top-yet this sample had only stood one day. The moulds were, of course, already developed, and had remained over from the previous contents of the bottle. Such growths have been clearly seen in uncoated bottles allowed to stand, and the risk of getting low results owing to moulds was pointed out by Matthews as a reason for analysing freshly drawn samples. The wax, however, appears to afford an anchorage for these growths. A third possibility, that the glass gave off phosphate, was tested at the start of the phosphate work and was negativednevertheless one batch of white soda glass bottles sent here for the analysis of sea-water samples did give off a little on prolonged standing. The changes in phosphate content of water stored for an appreciable time have recently (1927) been studied by Gill, but the discrepancies noted between the waxed and unwaxed bottles were obtained with samples within one or two days of their collection. That the silicate results are unaffected, whereas the phosphate results are too low, is due to the fact that the moulds take up no silicate. This leads on to a point of importance, the comparison of the seasonal changes in silicate and in phosphate. Neither the Phæocystis outburst nor those of species of Dinoflagellates result in a diminution of silicate, though phosphate is taken up. It is accordingly not surprising to note that there are discrepancies between the silicate and phosphate curves. Moreover, the silicate winter maximum varies from year to year far more than does the phosphate ; thus for the former the following maxima were obtained : 1923-'24, $200 \mathrm{mg}$. per m³. ; 1924-'25, $240 \mathrm{mg}$.; 1925-'26, $175 \mathrm{mg}$. ; 1926-'27, $260 \mathrm{mg}$. for the surface water at E1 ; for phosphate the corresponding values were: March, 1923, $36 \mathrm{mg}$. ; 1923-'24, $38 \mathrm{mg}$. ; then 33,40 , and 32 respectively, neglecting a high surface value where the water was not homogeneous. Moreover, a high silicate year, 1926-'27, $260 \mathrm{mg}$. may be a low phosphate year, $32 \mathrm{mg}$. As shown by salinity results and by the silicate analyses previously given (1926), water at E1 is but little affected by the outflow from the rivers flowing into Plymouth Sound. That enrichment from fresh water has nothing to do with these high values for silicate at E1 is shown by the fact that the surface value of November 24th, 1926, was $263 \mathrm{mg}$., the bottom $134 \mathrm{mg}$., yet the respective salinities were $35 \cdot 26$ and $35 \cdot 28 \%$. On February 15 th silica, after falling to 104 on December 31st, had risen to 260 at surface and bottom, the respective salinities being $35 \cdot 37$ and $35 \cdot 32 \%$. There is perhaps some indication that water of high salinity may also be high 
in silicate, for a 10-metre sample from E2 on November 24th had $144 \mathrm{mg}$. and $35.21 \%$, the values for E3 at the same time and depth being $379 \mathrm{mg}$. and $35.31 \%$. On the whole it must be concluded that no entirely satisfactory explanation can be reached as to the large variations in silicate shown by successive yearly maxima. The data available reveal a reasonably close correspondence between the vernal decrease in silicate and in phosphate, but in 1925 and to a lesser extent in 1926 silicate rose again in July, whereas phosphate remained low. The plotting of the silicate results beside those of phosphate and nitrate brings out the similarities and the differences between the behaviour of silicate and of the other two, between which the similarities largely predominate. In order, however, not to confuse the representation of the phosphate and nitrate analyses the silicate data have been omitted from the figures in the accompanying paper by Harvey. It is hoped that further work may afford an insight into the causes of the peculiar behaviour of the silicate.

In Table 4 are shown the phosphate analyses from four cruises to Ushant, also the surface and bottom temperatures. Perhaps the most striking result is the removal of phosphate from the surface water between $\mathrm{E} 1$ and E3, the E2 value being zero, although at $5 \mathrm{~m}$. it was $28 \mathrm{mg}$. per $\mathrm{m}^{3}$. By May, however, E1 has experienced an outburst of phytoplankton, resulting in a large fall in phosphate extending to the bottom; the accompanying rise in temperature shows that the water has undergone mixing. E2, however, has risen, and E3 is higher again; this may indicate an influx of phosphate rich water-the nitrate values obtained by Harvey undoubtedly do-but owing to the uncertainty of the correction for the deterioration in the standard solution, which unfortunately affected these results, too much reliance cannot be placed upon them. Since, however, in March the phosphate content at E2 was almost identical with that at E3 the differences noted in May do seem to indicate enrichment from an external source. Two very curious results were obtained in the July series, namely, $3 \mathrm{mg}$. at E2 bottom and $12 \mathrm{mg}$. at E3, with much higher values above. One is loath to attribute two unexpected results to analytical error, especially when they both happen to be bottom samples; but the nitrate gradient as found by Harvey was normal, and the salinity results show an almost isohaline column at the two stations, that for E2 (and E1) being slightly under $35 \cdot 1$, that for E3 over $35.3 \%$.

Table 5 records the phosphate content of deep water off the south-west coast of Ireland. For these samples and the temperature readings the author is indebted to Mr. G. P. Farran. 
TABLE 4.

Phosphate as $\mathrm{P}_{2} \mathrm{O}_{5}$ In Milligrams per Cubic Metre on the Plymouth-Ushant Line. “A” indicates the date on which the Analyses immediately above were made. Temperatures are shown at the bottom of the Table, B Denoting greatest Depth.

\begin{tabular}{rcccc} 
& & \multicolumn{3}{c}{ 11th of March. 1926. } \\
m. & E1 & Mid. & E2 & Mid. \\
0 & $25 \dagger$ & 11 & 0 & 5 \\
5 & 39 & - & 28 t & - \\
10 & 35 & - & 28 & - \\
15 & 37 & - & - & - \\
20 & - & - & - & - \\
25 & 39 & - & - & - \\
30 & - & - & - & - \\
50 & 37 & - & - & - \\
70 & 37 & - & - & - \\
90 & $*$ & - & 28 & - \\
110 & $*$ & $*$ & $*$ & $*$ \\
A & $13 / 3$ & do. & do. & do. \\
0 & $9 \cdot 5$ & $9 \cdot 8$ & $10 \cdot 4$ & $10 \cdot 3$ \\
B & $9 \cdot 4$ & - & $10 \cdot 0$ & -
\end{tabular}

\begin{tabular}{rrrrr} 
& & & \multicolumn{3}{c}{17 th of May. } \\
Fa & E1 & Mid. & E2 & Mid. \\
7 & $5 \dagger$ & 14 & 27 & 42 \\
28 & 12 & - & 21 & - \\
28 & - & - & 22 & - \\
- & 12 & - & - & - \\
- & - & - & - & - \\
- & 12 & - & 22 & - \\
- & $-\overline{4}$ & - & - & - \\
- & 14 & - & 22 & - \\
29 & 15 & - & - & - \\
- & $*$ & - & 24 & - \\
29 & $*$ & $*$ & $*$ & $*$ \\
do. & $19 / 5$ & do. & do. & do. \\
$10 \cdot 3$ & $10 \cdot 9$ & $11 \cdot 3$ & $11 \cdot 1$ & $11 \cdot 7$ \\
$10 \cdot 3$ & $10 \cdot 5$ & - & $10 \cdot 8$ & -
\end{tabular}

\begin{tabular}{rrrrr} 
& & \multicolumn{3}{c}{ 8th of July. } \\
41 & E1 & Mid. & E2 & Mid. \\
30 & 7 & 25 & 11 & 4 \\
30 & 4 & - & 4 & - \\
32 & 7 & - & 6 & - \\
- & 11 & - & 11 & - \\
36 & 13 & - & 20 & - \\
- & - & - & 30 & - \\
- & 12 & - & 24 & - \\
- & 12 & - & 24 & - \\
- & $*$ & - & 3 & - \\
34 & $*$ & $*$ & $*$ & $*$ \\
do. & $13 / 7$ & do. & do. & do. \\
$11 \cdot 4$ & $16 \cdot 9$ & $17 \cdot 2$ & $16 \cdot 9$ & $17 \cdot 4$ \\
$11 \cdot 1$ & $11 \cdot 8$ & - & 12.2 & -
\end{tabular}

\begin{tabular}{|c|c|c|c|c|c|c|}
\hline \multicolumn{3}{|c|}{24 th of November. } & \multicolumn{4}{|c|}{ 15th of Feb., 1927.} \\
\hline E1 & E2 & E3 & E1 & $\mathrm{E} 2$ & E3 & \\
\hline 28 & 30 & 20 & 24 & 13 & 24 & \\
\hline 24 & 23 & 20 & 28 & 29 & 24 & . \\
\hline - & - & - & - & - & - & 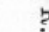 \\
\hline - & - & - & - & - & - & \\
\hline - & - & - & - & - & - & \\
\hline - & - & - & - & - & - & \\
\hline - & - & - & - & - & - & \\
\hline - & - & - & - & - & - & \\
\hline 26 & - & - & 28 & - & - & \\
\hline * & 22 & - & * & 29 & - & \\
\hline * & * & 20 & * & * & 24 & \\
\hline $26 / 11$ & do. & do. & $24 / 2$ & do. & do. & \\
\hline $12 \cdot 2$ & $12 \cdot 0$ & $12 \cdot 2$ & $9 \cdot 4$ & $9 \cdot 8$ & $10 \cdot 0$ & \\
\hline $12 \cdot 2$ & $12 \cdot 0$ & $12 \cdot 3$ & $9 \cdot 4$ & $9 \cdot 8$ & 101 & \\
\hline
\end{tabular}

$\dagger$ As previously noted, values for March and May may be high.

Mid. = midway sample.

t Temp. $=10 \cdot 1^{\circ}$

* Indicates bottom has been reached before depth shown. 


\section{TABLE 5.}

Phosphate as $\mathrm{P}_{2} \mathrm{O}_{5}$ In Millligrams per Cubic Metre and TemperaTURE OFF the S.W. Coast of Ireland at $50^{\circ} 34^{\prime}, 11^{\circ} 17^{\prime} \mathrm{W}$., AND $49^{\circ} 20^{\prime}$ N., $9^{\circ} 00^{\prime}$ W. RESPECTIVELy. "A " DENotes DATE ON WHICH ANALYSIS WAS PERFORMED.

\begin{tabular}{rcccc|ccccc} 
& Aug. 17th, '26. & \multicolumn{2}{c}{ Feb. 19th, '27. } & \multicolumn{2}{c}{ Aug. 12th, '26. } & \multicolumn{2}{c}{ Feb. 18th, '27. } \\
$\mathrm{m}$. & $\mathrm{t}^{\circ}$ & $\mathrm{P}_{2} \mathrm{O}_{5}$ & $\mathrm{t}^{\circ}$ & $\mathrm{P}_{2} \mathrm{O}_{5}$ & $\mathrm{~m}$. & $\mathrm{t}^{\circ}$ & $\mathrm{P}_{2} \mathrm{O}_{5}$ & $\mathrm{t}^{\circ}$ & $\mathrm{P}_{2} \mathrm{O}_{5}$ \\
0 & $17 \cdot 1$ & 0 & $10 \cdot 7$ & 24 & 0 & $18 \cdot 2$ & 0 & $10 \cdot 0$ & 16 \\
100 & $11 \cdot 1$ & 38 & - & - & 141 & - & - & $9 \cdot 9$ & 27 \\
402 & - & - & $10 \cdot 5$ & 38 & 146 & $10 \cdot 9$ & 35 & - & - \\
768 & $9 \cdot 2$ & 51 & - & - & $*$ & $*$ & $*$ & $*$ & $*$ \\
860 & - & - & $9 \cdot 3$ & 48 & & & & & \\
$\mathrm{~A}$ & - & $4 / 10$ & - & $3 / 3$ & $\mathrm{~A}$ & - & $4 / 10$ & - & $3 / 3$
\end{tabular}

The analyses show clearly that the deep water is very well supplied with phosphate, and more so in summer than in winter when the equalisation of temperature points to mixing with the surface water, the latter being thereby enriched. The figures are probably subject to some error due to storage, but not enough to invalidate the conclusions. The complete removal of phosphate from the surface water in summer is noteworthy. Harvey, in his nitrate paper, records $9 \mathrm{mg}$. nitrate nitrogen per $\mathrm{m}^{3}$. for the deep-water station in August and $84 \mathrm{mg}$. for the corresponding surface sample in the shallower station, so in these waters nitrate appears to be in excess of phosphate. The phosphate results are quite in accord with those for 1924 (Atkins, 1925, Table 13) and for 1925 (1926, Table 10) for the same region.

\section{TABLE 6 .}

Phosphate as $\mathrm{P}_{2} \mathrm{O}_{5}$ In Milligrams Per $\mathrm{M}^{3}$. in the Atlantic, Para to Liverpool route, Surface Samples taken by R.M.S. Hildebrand DURING 1926-'27. “A " DENOtes DATE ON WHICH ANALYSES WERE performed. The Figures are Averages between the Latitudes AND LoNGITUdES GIVEN.

\begin{tabular}{cccccc} 
Lat. N. & Long. W. & $\begin{array}{c}\text { Apl. 16th- } \\
29 \text { th. }\end{array}$ & $\begin{array}{c}\text { June 24th- } \\
\text { July 8th. }\end{array}$ & $\begin{array}{c}\text { Aug. 19th- } \\
\text { Sept. 2nd. }\end{array}$ & $\begin{array}{c}\text { Dec. 24th- } \\
\text { Jan. 6th. }\end{array}$ \\
$0^{\circ}-5^{\circ}$ & $47^{\circ}-43^{\circ}$ & 11 & 23 & 17 & 6 \\
$5^{\circ}-15^{\circ}$ & $43^{\circ}-34^{\circ}$ & 19 & 16 & 3 & 3 \\
$15^{\circ}-25^{\circ}$ & $34^{\circ}-24^{\circ}$ & 16 & 17 & 9 & 3 \\
$25^{\circ}-35^{\circ}$ & $24^{\circ}-14^{\circ}$ & 12 & 7 & 6 & 3 \\
$35^{\circ}-48^{\circ}$ & $14^{\circ}-7^{\circ}$ & 23 & 3 & 9 & 5 \\
\multicolumn{2}{r}{ Mean of all } & 16 & 12 & 8 & 4 \\
\hline \multicolumn{2}{r}{ No. analysed } & 21 & 18 & 17 & 14 \\
A & $21 / 5$ & $20 / 7$ & $4 / 10$ & $17 / 1$
\end{tabular}


Table 6, which is a continuation of Table 12 (1926) recording results for 1925, shows the values obtained for surface samples on the ParaLiverpool route. The analyses are subject to an unknown storage error, but seem to indicate that the highest values occur in April, especially near the eastern end, but in June at the western end. The lowest values were found in August and December. On the whole the results are higher than for 1925 .

\section{The Estimation of Phosphate in Sea-Water.}

The method of Denigès, which has been in use in this laboratory since 1923, has recently been compared with other methods involving the use of organic reducing agents instead of stannous chloride. The conclusion was reached (Atkins and Wilson, 1926) that in delicacy and rapidity Denigès' method was superior to the others. Trouble due to the appearance of a yellow tint, converting the clear blue of the reduced phosphomolybdate into a greenish colour, has been reported. The remedy for this consists in adding only one drop of the stannous chloride reagent instead of five. The method has been criticised on the score that the measurement of the stannous chloride by drops is not an exact measure, also that as ordinarily made up the strength of the latter is only roughly constant, about $0 \cdot 1 \mathrm{grm}$. of tin dissolved and made up to 10 cubic centimetres. With the quantities of phosphate found in natural waters the addition of one drop of this reagent means that a very large excess is present, so that the ratio of phosphate to reagent is quite unaffected, for practical purposes, by any such variation in the strength of the reagent. The method standardised in Meyerhof's laboratory (Lohmann and Jendrassik, 1926) in which eikonogen, suitably purified, is used as the reducing agent has not been tried for sea-water, because the necessity of boiling the water for five minutes would add too greatly to the time required for dealing with large numbers of samples in view of the fact that Denigès' method has been found reliable and rapid. It may here be noted that Wattenberg (1926) attributes the method to E. G. Moberg, who appears to have used it in the Pacific some years after Denigès' papers led to the method being used elsewhere for sea-water.

\section{The Estimation of Silicate in Sea-Water.}

The colorimetric method of Diénert and Wandenbulcke (1923) was used, adding 2 c.c. of ten per cent ammonium molybdate, followed by four drops of fifty per cent (by volume) sulphuric acid to 100 c.c. of seawater. The limit detectable is close to $0.04 \mathrm{mg}$. per litre $\mathrm{SiO}_{2}$. Though this is so, above the detectable limit much smaller differences than 0.04 can be distinguished. Thus a value $0.094 \mathrm{mg}$. p.l. or $94 \mathrm{mg}$. per $\mathrm{m}^{3}$. 
was obtained for a surface sample and $108 \mathrm{mg}$. for a bottom sample. To make sure that the difference was a real one the colorimeter column was altered, and it was found that a reading $100 \mathrm{mg}$. was definitely too light, 128 was clearly too high, 120 was a near match, but too high. The value first found, 108, was therefore correct, and a difference of $10 \mathrm{mg}$. per $\mathrm{m}^{3}$., or $0.01 \mathrm{mg}$. p.l., can be distinguished. This is only about onetenth the delicacy of the Denigès' phosphate reaction.

In order to see whether exceptionally high phosphate values could affect the accuracy of the silicate estimations a solution of $\mathrm{KH}_{2} \mathrm{PO}_{4}$ equivalent to $100 \mathrm{mg}$. p.l. $\mathrm{P}_{2} \mathrm{O}_{5}$ was analysed as if it were silicate; the yellow tint it gave was only equivalent to $0.3 \mathrm{mg}$. p.l. $\mathrm{SiO}_{2}$. As the solution of phosphate taken was over 2000 times as concentrated as is sea-water with respect to this salt, it is obvious that its presence is quite without effect upon silica estimations.

\section{SUMMARY.}

1. A comparison of the strength of the wind, Beaufort Scale, and of its direction during the periods when the vernal diatom outburst caused phosphate depletion of the surface water, has failed to indicate that there is any connection between either strength or direction and the date of the outburst. The spring sunshine still appears to be the important factor at E1.

2. The sequence of the years studied as regards the main spring diatom outburst deduced from phosphate depletion at Station E1 is as follows: 1924, early March; 1926, late March to early April ; 1925, early April ; 1923, early May.

3. Phosphate regeneration may take place at or near the surface more rapidly than at the intermediate depths. The bottom is the most important source of phosphate, but its regeneration throughout the whole water column takes place to a lesser extent.

4. In 1926 the surface water at the mid-Channel station, E2, had become completely void of phosphate by March 11th, while this salt was still abundant at E1 and not exhausted at E3. A diatom outburst need not therefore originate near the coast, but may take place where local conditions are favourable.

5. Waxed bottles, used for storing water for silicate analysis, may harbour moulds which rapidly reduce the phosphate content of the water sample.

6. The vernal fall in phosphate and in silicate shows good agreement, but a summer rise in silicate has been observed while phosphate has 
remained low. Since Phæocystis and the Peridineæ take up no silicate the two radicles should only vary together when diatoms are the main constituent of the phytoplankton.

7. There is a considerable difference between the yearly maxima for silicate at E1, and a high silicate year may be a low phosphate year; the variations in the latter are, however, less.

\section{REFERENCES.}

Angström, A. 1924. Solar and terrestrial radiation. Q. J. Roy. Meteorological Soc., 50, 121-126.

Atkins, W. R. G. 1923, 1925, 1926. The phosphate content of seawater in relation to the growth of the algal plankton. J. Marine Biol. Assoc., 13, 119-150, 700-720 ; 14, 447-467.

Atkins, W. R. G. 1923, 1926. Seasonal changes in the silica content of natural waters in relation to the phytoplankton. J. Marine Biol. Assoc., 13, 151-159; 14, 89-99.

Atrins, W. R. G., and Edith G. Wilson. 1926. The colorimetric estimation of minute amounts of compounds of silicon, of phosphorus and of arsenic. Biochem. J., 20, 1223-1228.

Atkins, W. R. G., and Edith G. Wilson. 1927. The phosphorus and arsenic compounds of sea-water. J. Marine Biol. Assoc., 14, 609-614.

Brandt, K. 1916-1920. Über den Stoffwechsel im Meere. 3 Abhandlung. Wiss. Meeresuntersuch., Abt. Kiel, 18, 185-430.

Diénert, F., and F. Wandenbulcke. 1923. Sur le dosage de la silice dans les eaux. C.R. Acad. des Sciences, Paris, 176, 1478-1480.

GILL, R. 1927. The influence of plankton on the phosphate content of stored sea-water. J. Marine Biol. Assoc., 14, 1057-1066.

Hatnes, W. B. 1925. A comparison of the radiation recorders at Rothamsted. Q. J. Roy. Meteorological Soc., 51, 95-100.

Harvey, H. W. 1926. Nitrate in the sea. J. Marine Biol. Assoc., 14, $71-88$.

Herdman, W. A., Andrew Scott, and W. J. Dakin. 1910. Intensive study of the marine plankton around the south end of the Isle of Man. Pt. III. Trans. Liverpool Biol. Soc.

Lohmann, K., and L. Jendrassik. 1926. Kolorimetrische Phosphorsäurebestimmungen im Muskelextrakt. Biochem. Zeitschr., 178, 419-426. 
Marshall, S. M., and A. P. ORR. 1927. The relation of the plankton to some chemical and physical factors in the Clyde Sea area. J. Marine Biol. Assoc., 14, 837-868.

Matthews, D. J. 1916, 1917. On the amount of phosphoric acid in the sea-water off Plymouth Sound. J. Marine Biol. Assoc., 11, 122-130 and 251-257.

Poole, H. H., and W. R. G. Atkins. 1926. On the penetration of light into sea-water. J. Marine Biol. Assoc., 14, 177-198.

RABen, E. 1916-1920. Quantitative Bestimmung der im Meerwassergelösten Phosphorsäure. 3 Abhandlung. Wiss. Meeresuntersuch. Abt. Kiel, 18, 1-24.

Wattenberg, H. 1926. Bericht über die chemischen Arbeiten. Die Deutsche Atlantische Exped. auf den forschungs- und vermessungsschiff "Meteor." Zeitschr. d. Gesellschaft für erdkunde zu Berlin. Nr. 1. 
